\title{
Networking vs. Allying: \\ The Decision of Interest Groups to Join Coalitions in the US and the EU
}

\author{
Christine Mahoney \\ Syracuse University \\ Moynihan European Research Centers \\ Moynihan Institute of Global Affairs \\ Syracuse, NY 13244
}

Paper to be presented at the bi-annual European Union Studies Association meeting, Montreal, Canada May 17-19, 2007. Thank you to Frank Baumgartner, Donna Bahry, Jeffrey Berry and the anonymous reviewers for comments on earlier drafts of this paper.

This paper was published in the Journal of European Public Policy Vol. 14.2 


\begin{abstract}
Ad hoc issue coalitions allow advocates to pool resources and signal support of their position to policymakers. Ad hoc coalitions, however, are not formed in every instance; groups do not always choose to ally since there are also costs associated with membership. To understand why organizations sometimes decide to ban together and sometimes choose to forge ahead alone, I argue we must consider the institutional structure of the political system; the nature of the issue at hand; and finally the characteristics of the interest group itself. This theory is tested on original data based on interviews with a 149 lobbyists active on a random sample of 47 policy issues in the United States and the European Union. The results show that EU advocates are building formal coalitions at a much lower rate than their American counterparts. The qualitative evidence suggests that the democratic accountability of policymakers may explain these differences.
\end{abstract}

Key Words: Coalitions; European Union; Interest Groups; Lobbying; United States 


\section{Introduction}

Nearly every scholarly work on lobbying mentions networking of one type or another

(Heclo 1978; Sabatier 1988; Salisbury et al. 1987). Advocates share tidbits of information after committee meetings, forward emails with talking points, hold conference calls to get allies up-to-speed on policymaking developments, send joint letters to policymakers; all of these activities can be referred to as networking or coalition activity.

Networking ranges on a continuum from very informal and loose, comprised of occasional information sharing, to highly coordinated enterprises with logos, letterhead and secretariats. Almost without exception, all lobbyists engage in some degree of networking; not all advocates pursue more formalized ad hoc issue coalition action.

What determines how coordinated like-minded advocates choose to be? What factors lead advocates to work in more formal ad hoc issue coalitions rather than simply share information informally through loose networks? This paper seeks to answer these questions by analyzing original data based on 149 in-depth interviews with advocates in Washington D.C. and Brussels lobbying on a random sample of 47 policy issues in the United States and the European Union.

Previous studies of lobbying in both the U.S. and the EU have demonstrated that advocates (whether interest groups, corporations, or institutions) sometimes choose to work on their own (Salisbury 1984; Coen 1997), sometimes pursue their lobbying goals through their associations or federations (McLaughlin, Jordan \& Maloney 1993; Pollack 1997; Bouwen 2002; Walker 1991), and other times opt to work through a hired lobbying firm (McLaughlin, Jordan \& Maloney 1993; Bouwen 2002; Lahusen 2002). Ad hoc issue coalitions constitute another alternative. It is important to better understand this 
alternative route advocates use to advance their positions since coalition action may have differential effects on interest group influence and since different types of interests may be benefiting from the strategy (see Mahoney \& Baumgartner 2004). Do advocates join ad hoc issue coalitions when they face a particularly difficult fight? Do they join when they have the resources available to contribute to the collective? Are citizen interests more likely to ban together than corporate interests? Numerous studies look at certain aspects of ad hoc coalition activity, but the focus has largely been confined to the US case, and little research has sought to determine the effect of institutional design on coalition activity. This paper seeks to fill this void. It does not attempt to determine if coalitions are more influential than other forms of interest representation, but rather aims to determine what contextual factors lead advocates to choose the issue coalition route to influence public policy.

The first section of the paper reviews the literature on interest group activity in coalitions. This section includes a definition of "ad hoc issue coalitions," as well as a discussion of why they are important to interest groups participating in the policymaking process. The second section identifies three sets of factors that appear to play a role in the decision of advocates to join issue coalitions and lays out the theoretical expectations about how these three groups of factors should influence formal coalition activity. The third section explains the research design and data. The fourth and final section presents the empirical analysis of the factors influencing coalition activity. 


\section{Previous Research on Interests Groups in Coalition}

As mentioned, networking is ubiquitous. Lobbyists need information on policy proposals, intelligence on policy developments, and knowledge of the positions of other advocates active on a policy debate. Much of this can be gathered from simply talking with other lobbyists and thus some level of networking is expected on every issue.

But the question remains: why move beyond networking to build more formal ad hoc issue coalitions? By ad hoc issue coalitions I mean a very specific type of coalition of groups - one which forms for a single discrete issue fight. Pijnenburg (1998) notes that ad hoc issue coalitions are characterized by low levels of formalization (compared to formal interest group organizations) and high levels of autonomy for the coalition's members. They are established in the short to medium term for the duration of a single legislative or regulatory debate. While some issue coalitions may last longer, they remain a coalition of autonomous groups, they do not establish their own direct membership or organizational structure. There is usually a coalition leader organizing the efforts of the members, regular meetings of the coalition members, joint lobbying actions such as joint letters, advertisements or press conferences and very often an official name for the coalition and even letterhead and a secretariat acting as the headquarters of the coalition (Berry 1989). Ad hoc coalitions are most often composed of different types of groups or associations representing different sets of interests. The concept of ad hoc issue coalitions should not be confused with Sabatier’s (1988) concept of “Advocacy coalitions" which is a much broader theoretical construct than a discrete set of groups that have organized themselves for a single issue fight. 
Groups could choose to work alone, or through their federation, or through a hired lobbyist but the ad hoc advocacy coalition offers unique advantages. From the literature it is clear that coalitions can be beneficial to interest groups in a political fight in two regards: 1) The coalition can signal to policymakers that a policy position has the support of a large and varied group of interests; and 2) The coalition can provide a framework for more efficient use of resources.

Scholars from Mayhew (1974) to Kingdon (1995) to Esterling (2005) have suggested that policymakers look for signs that a policy proposal has broad support. In political systems where policymakers are elected, they will want to know whether a vote in favor of a provision could prove later to be detrimental to them in an election. If a large majority of the public is opposed to a proposal which a policymaker supports, he or she could pay for it in the next election (Mayhew 1974; Arnold 1990). Thus coalitions can signal to policymakers where the bulk of support lies. Coalitions can also indicate that advocates have worked out differences among themselves before approaching government officials and thus their final position is one that can be supported by a the majority of the legislature and the public (Heclo 1978; Hula 1995, 1999). A coalition can thus garner more political support for a policy position by indicating a large set of interests already support the position.

From a resource efficiency standpoint, coalitions have the potential to pool the resources of their members, and thus coalition activity could be more economical. As Hojnacki notes "almost all discussions of interest group coalitions refer to resource sharing as a benefit of coalition advocacy (Berry 1977, 1989; DeGregorio and Rossotti 1995; Hula 1995; Ornstein and Elder 1978; Scholozman and Tierney 1986)” (cited in 
Hojnacki 1998, 439). Some tactics like running issue advertisements can be very expensive, but if everyone in the coalition contributes some funds it lightens the burden on any one advocate. Moreover, if coalition members divide up the lobbying work among them they can more efficiently use the resources of the collective in the given policy fight. In addition, joining a coalition can be a relatively low-cost tactic and a rational lobbyist may incorporate this one tool along with many others in their advocacy strategy (Coen 1997; Pijnenburg 1998).

Since coalitions send cues to policymakers about the desirability of a policy option and since they pool scarce resources, advocates have an incentive to join them. However there are also costs associated with coalition membership; some money and time need to be devoted to the coalition and a group may need to modify their position on an issue to be inline with the coalition position. In addition, groups in crowded advocacy communities have an incentive to differentiate themselves from other interest groups in order to attract membership (Browne 1990). In short, there are also forces pushing groups to work alone. Thus we would expect groups to join coalitions in instances where there is a greater need than usual to signal to leaders the breadth of support for a position and a greater need to pool resources.

Previous research on ad hoc issue coalitions has addressed many questions about the behavior of advocates within coalitions but less about why groups join them initially. Hojnacki (1998) investigates when US groups in coalition free-ride and when they decide to be active contributors to the collective effort (for a similar study see Heaney 2004). Hula (1995) also looks at why some US groups become coalition leaders while others are members in name but devote very few resources. He argues that groups that constitute the 
"core" of the coalition are those with the most at stake, while those in the "periphery" are only tangentially interested in the policy outcome.

Some studies have looked more directly at why advocates join coalitions. Hula’s (1999) later work lays out a range of resource incentives that coalitions present to potential members - the traditional monetary resources, but also informational resources and political contact resources. He argues that resource sharing is an incentive that attracts members to a coalition even though they may need to modify their position to be included in the coalition. Pijnenburg's (1998) exploratory case study in the EU leads him to similar conclusions about the importance of resource incentives, specifically the provision of insider information and how the "insider" status of some coalition members can be shared with other members.

Hojnacki (1997) models the decision to join a coalition as a cost-benefit analysis. Her evidence shows that US groups will not join a coalition when the costs of joining the coalition outweigh the potential benefits that the coalition might provide. Holyoke (2004) models the decision of advocates to join an ad hoc issue coalition as a bargaining process in which two advocates are in conflict and they can choose to cooperate and work toward a new policy position that pleases them both (through coalition building) or they can choose to engage in an advocacy war. The bargaining model suggests advocates’ decisions to be very much influenced by the decisions of their potential coalition partner/ competitor. Coen's (2004) work also highlights the importance of other actors in the advocacy community as well as institutional pressures when considering the rise of ad hoc coalitions in the EU environmental domain in the 1990's. He notes that competition 
among groups for sought after access to restricted policy forums drove business interests to ally and even modify their positions to gain entrance.

\section{Institutions, Issues and Interests: Factors Influencing the Decision to Join an Advocacy Coalition}

As the preceding section has shown, previous studies of ad hoc issue coalitions have considered the importance of a number of issue characteristics (i.e. conflict, importance of issue, position of other actors on an issue) and some interest group characteristics (i.e. resources, issue positions) on coalition membership, but there has been little research on the effect of institutional design on coalition formation. This omission is understandable since most studies of coalition activity are restricted to a single political system. However, a comparative research design opens the door to exploring this question. Following Kingdon’s (1995) approach to understanding political phenomena, I work toward a more holistic model, recognizing that various streams of factors merge to determine the decision to join a coalition. Specifically, I argue that three critical streams of factors must be taken into consideration: the institutional structure in which the advocate is operating, the nature of the policy issue at hand, and characteristics of the interest group.

At the institutional level, I hypothesize that the democratic accountability of policymakers is a key institutional factor when we seek to understand the decision to join a coalition. As discussed above, ad hoc issue coalitions have two advantageous qualities: they pool resources and they signal to policymakers the breadth of support for a policy position. All things equal, advocates should have some base level of attraction to 
coalitions since they efficiently pool resources, but that attraction should increase in political systems where policymakers are highly attuned to cues about public support for policy proposals, as they are when they are directly elected.

While there is variation on the level of democratic accountability within the EU, with the EP being more democratically accountable then the Commission and Council, the EU institutions are largely not democratically accountable to the people - as is often lamented on the large literature on the democratic deficit (Weiler et al. 1995; Follesdal \& Hix 2006). In addition, the democratic accountability of the EP, which is directly elected, is greatly reduced due to the use of party lists by the member states during EP elections (Kreppel 2001). Furthermore, Princen and Kerremans note that the EP "is largely shielded from direct popular control because EP elections are usually decided on domestic themes and popular interest in the EP's work remains low between elections” (2005, 8). In the US on the other hand, members of both the House and Senate are highly aware of their electoral vulnerability and are thus highly accountable to the people in direct elections. Thus, a comparative US/EU study can provide some insight into the role of democratic accountability on coalition activity. Of course, there are other differences between the two systems in addition to the differences in democratic accountability, thus qualitative and interview-based evidence will be used to assess if accountability is a likely factor in explaining any observed differences in coalition activity.

When policymakers are directly accountable to their constituents they should be more susceptible to claims about the broad support of interests for a specific proposal. Thus, we should expect more ad hoc issue coalitions to form in the US than in the EU. This is in line with Bouwen's (2002) work that argues that information on encompassing 
interests (which coalitions provide) are less desired by the European Commission than expert knowledge (which coalitions do not have a competitive advantage in producing) since the Commission is the primary target of lobbying in the EU.

There are, of course, other system differences that could account for differences in the prevalence of coalitions in the two systems. First, the EU system is characterized by multilevel governance. It could be that while ad hoc issue coalitions may not form at the EU level (the focus of this study) they may be forming in the member-state capitals. National-level lobbying remains a significant focus of European interests (Kohler-Koch 1994; Beyers 2002; Imig \& Tarrow 2001). Second, EU groups may have less resources to devote to an ad hoc coalition. While Brussels has long been making important public policy, some industries, sectors and interests still find it difficult to encourage their national organizations to contribute significant amounts of funding to the EU level. Some Eurogroups may simply not have the resources at their disposal to pass up to another level of organization. Third, there could be a difference in the composition of the interest group communities in the US and the EU - with the US having many more smaller specialized groups and the EU having more encompassing umbrella organizations. The smaller specialized groups in the US would have more reason to ban together than larger Euro-federations of national associations. To parse out which of these factors, or combinations thereof, are most likely at play, I will rely on qualitative data from in-depth interviews in addition to quantitative data. 


\section{Issues \& Interests}

The characteristics of the issue at hand should also determine whether a coalition is established on a given policy debate. First, highly conflictual issues may more likely lead to coalition formation because conflict gives groups an incentive to band together to face a common threat (Gais and Walker 1991; Hojnacki 1997; Whitford 2003). Advocates need to signal the strength of their position relative to their competitors to elected officials following the case. Thus, it is expected that the higher the conflict among actors on the issue, the higher the probability of coalition membership. Second, highly salient issues are also expected to lead to coalition formation since these types of issues require that advocates demonstrate a broad base of support. In addition, issues that are the object of a great deal of public attention may require advocates to engage in more costly tactics such as issue advertisements or publicity raising events and thus pooling resources may be even more attractive on such costly issues. Third, the scope should play a role. Larger scope issues that affect large portions of the population can be costly since advocates may need to convey their position to the affected public. In addition, large-scope issues, which will have significant implications for large sections of the electorate, should drive groups to signal their strength to policymakers through allying in a coalition. Thus, the expectation is that the larger the scope of the issue, the higher the probability of coalition membership.

Some authors have suggested some types of organizations are less likely to engage in coalition activity than other types of advocates. Clark and Wilson (1961) suggest that cooperation is more likely among utilitarian groups and less likely among purposive groups, largely because the latter are more restricted in their activities due to 
incentive systems $(1961,162)$. The idea here is that the added benefit of signaling and resource pooling do not outweigh the ideological cost of potentially having to modify one's position to fit with the coalition. Thus actor type should play a role in the decision to join a coalition, with the expectation that ideological citizen groups should be less likely to align.

Organizational resources should play a role in the decision to work through a coalition. Resource mobilization theorists emphasized the importance of resources in interest group mobilization and advocacy efforts (McCarthy \& Zald 1978; Cress \& Snow 1998). In order to mobilize for a policy debate, resource-poor groups need to identify resource sources and spend resources conservatively. Since coalitions pool resources, coalition activity could stretch scare resources. Wealthy advocates on the other hand, such as trade associations and corporations, do not face the same type of hurdles to mobilize. As an issue rises on their agenda, resource-rich advocates can more easily mobilize for the debate without having to rely on like-minded interests. Indeed this may be the cause for Caldeira and Wright's findings in their study of amici curiae activity which showed public firms and peak associations to be less likely to work in coalition (1990, 799). I use staff size as a proxy for resources and test whether organizational resources influence the decision to join a formal coalition. Since coalitions pool resources, the expectation is that resource-poor groups will be more likely to join coalitions.

\section{Research Design and Data}


To test the effects of institution, issue and interest factors on the decision to join a ad hoc issue coalition the project presented here collected data on a random sample of actors, lobbying on a random sample of cases in the two political systems of the US and the $\mathrm{EU}^{1}$. A random sample of American lobbyists was drawn from a sampling frame of all Lobby Disclosure reports registered in 1996 (see Baumgartner \& Leech 2001). A random sample of EU lobbyists was drawn from a sampling frame I developed through combining the 2004 Registry of the European Parliament, the 2004 Commission registry of civil society organizations (CONECCS) and the 2004 European Public Affairs Directory.

Advocates who agreed to be interviewed were asked to describe the issue on which they had most recently been working. This served to generate a true random sample of issues, rather than the largest, most interesting or most important issue to the organization. This data collection process led to a random sample of 21 issues in the US and 26 issues in the $\mathrm{EU}^{2}$. In addition, interviewees were asked to identify the other major actors engaged in the policy debate who were then interviewed, forming the snowball portion of the sample.

Respondents were also asked about the background of the issue they were working on, the tactics they engaged in, coalition participation, the arguments they were employing, among other questions. For each advocate interviewed, I coded if they were members of any ad hoc issue coalitions, the names of those coalitions, and if any other coalitions were engaged in the policy debate of which they were not members.

In addition to data collected through the in-person interviews I also collected information on the issues and the individual organizations. Small-scale case studies were 
conducted on each of the issues based on news coverage and official government publications. This research was the basis for the coding of the issue variables of Scope and Conflict. Salience was measured by news coverage of each issue collected through Lexis-Nexis searches. For the US cases, salience is indicated by the number of New York Times articles on the issue in the two year period of research, and for the EU cases salience is indicated by the number of Financial Times articles.

\section{Empirical Findings}

As expected more ad hoc issue coalitions were formed in the US than the EU. Across the sample of 21 US issues a total of 22 ad hoc issue coalitions were established. In the EU, only 5 coalitions were formed across 26 issues. Some issues prompted multiple coalitions to form like the Transportation Reauthorization issue in the US on which 7 ad hoc issue coalitions formed or the Packaging and Packaging Waste issue in the EU for which 2 coalitions mobilized. Looking at the number of issues in the US and the EU on which one or more coalitions formed, shows $57 \%$ of US issues with coalition activity while only 15\% of EU issues exhibit coalition activity, as seen in Figure 1a.

[Figure 1 A \& B about here]

Looking at it at the advocate level, in the US 19 of the 65 advocates interviewed, or $29 \%$, joined ad hoc coalitions established on the issue at hand. In the EU, only 8 of 82 advocates or $9.8 \%$ of advocates reported joining an ad hoc issue coalition as seen in Figure 1b.

The majority of issues in the US have coalitions organizing on them, while coalition activity in the EU is quite rare. However, not every advocate in the US is opting 
to work through coalitions on every issue, $70 \%$ of US advocates are not joining coalitions on some issues. The nearly ubiquitous nature of coalitions across the 22 issues in the US sample suggests that a leader often forms a coalition, making the lobbying route available to advocates active on the issue. Whether the coalition then become one of the most important actors, or whether prominent advocates work through it however appears to be a different story. The data makes clear though, at either the issue or individual level, the rate of coalition activity remains much higher in the US than the EU.

The simple differences between coalition activity in the US and the EU are not enough to determine if electoral accountability is driving the difference or if another factor explains these system level differences. However, the hypothesis that advocates active in a system with greater electoral accountability will be more likely to work through coalitions does find qualitative support in addition to the quantitative evidence presented above.

In the US, a number of lobbyists active in coalitions describe the attempt to convey the breadth of support for their position. A company lobbyist on the CAFÉ debate described a coalition of which they were a member:

The Coalition for Vehicle Choice is a very broad group - there are auto companies in it, the suppliers are in it, the dealers are in it, but it also includes some of the safety organizations that are concerned about highway safety and some of the consumer groups like, the Snowmobile Association, the recreation industry has been involved in this as well. So we've tried to be as creative and broad - reaching out to other groups - as we could be.

Similarly, a trade association lobbyist on the marine employment issue tried to convey the breadth of the coalition she was leading: "In the coalition, we have over a 100 people 
in the coalition, all different types of people, the marine related people, people from the insurance industry - we thought they would have a problem with it, they’ve actually joined the coalition.”

In addition to conveying the sheer size of support, it can be equally important to convey to elected policymakers that different types of organized interests are on board. Some have referred to coalitions which have traditionally opposing interests allying on a certain issue as “strange bedfellow coalitions.” These are instances such as the extreme left and the extreme right agreeing on free speech issues; or leftist human right groups and conservative religious groups agreeing on foreign policy proposals against oppressive regimes. In the US sample, strange bedfellow coalitions could be found between business and the environmental community. Advocates active on such coalitions emphasized the power of such alliances. A trade association lobbyist on the Wind Energy Tax Credit case explained: “That's good when you can get disparate parties signing on to a letter, a Member of Congress sees a letter and it's signed by the Chamber of Congress and the Sierra Club, how often do you see that?”

The aim then is to build as big and as broad of a coalition as possible. In this way advocates can signal to elected policymakers that a large majority of the electorate will likely support them, if they support this proposal. This electoral signaling in effect says to elected officials: vote for this without concern for negative political consequences.

There is also evidence that pooling resources is part of the decision. While coalitions are in part about sending signals to policymakers they are also about resource efficiency. A citizen organization active on the issue of disability rights in the welfare program described how the members of the CCD tried to stretch their resources by 
divvying up meetings with Members of Congress. A member of the Basic Education Coalition painted a similar picture of trying to magnify the impact of the coalition members. She explained how coalition members pooled resources to finance a trip for Members of Congress to education projects in developing countries. Thus in the US we see strong evidence that coalition building is about sending a 'big and broad' message to elected officials, but stretching resources is also a goal.

In the EU, the few actors that reported coalition activity focused more on resource sharing, rather than conveying the sheer breadth of support. As one of the members of the coalition on the Consumer Credit Directive explained the aim was to share information and work out the details of their position before they approached policymakers:

We set up last year the EBIC - the European Banking Industry Committee - and that has as members ourselves, the European Banking Federation, the European Savings Bank Group, and some others, it is a kind of platform, the aim is to find our convergences, and once we do the outcome is the drafting of letters to the Commission to the EP.

Similarly a trade association active on the packaging environment indicator in the Packaging and Packaging Waste Directive described how the goal of the coalition was to work out technical details:

We are really, I don't want to say the authority, but the major player when it comes to packaging. Now each of the major sectors, or materials also have their own organizations - beverage has its own, plastic, paper, and each has its own sub-section dealing with packaging and some resource devoted to that. We work in coalition with them...So in those we exchange ideas, make sure we are all singing from the same hymn sheet.

Finally, a member of the coalition on solvent producers and users on the Clean Air for Europe issue emphasized that coalitions are more about hashing out the details and 
exchanging information than sending a political message. He noted that they met 16 times a year to debate the current problems and decide on a common position.

In further evidence of the resource pooling and not political signaling aim of coordinated activity in the EU, advocates reported high levels of networking. Though they may have not needed to convey the magnitude of their support, and thus did not need to establish an ad hoc issue coalition, advocates active on the CAFÉ, REACH, Data Retention, and Animal Transport debates all engaged in highly organized networking. A trade association on the Data Retention issue explained: "We decided to work closely with the other E-associations, so EUROISPA, GSM Europe, ECTA - the smaller telecoms companies, we did a lot of lobbying, we wrote letters, we did a lot of information gathering and sharing.” The coordination of industry on the CAFÉ debate was nearly surgical in its precision, organized at the top by the pan-EU business association UNICE. Each of the lobbyists described divvying up tasks, sharing information and working in synchronization; as one trade association explained:

I can't possibly attend all the meetings. But we are always represented by UNICE, there is always one member of the working group at the meetings and then they share that and we circulate documents around. UNICE has a small working group set up on CAFÉ and it meets fairly often, once a month, and so we stay up to date that way... And UNICE is sending a letter to all the Commissioners, and we divide it up in the working group, so electricity has good contacts with DG Energy and so they will work on them, and we will talk with Enterprise, and it goes like that.

If the aim was to signal to policymakers the breadth of their support it may have made sense to form an official ad hoc issue coalition, with a catchy name, and send out countless letters advertising their large and diverse membership. As it was, their aim was 
resource efficiency and they therefore organized their work and resource pooling behind the scenes.

Highly professional networking isn't reserved for industry alone. An environmental organization active on REACH described how the green EU groups worked to coordinate their activities:

We all try to coordinate as much as possible so as to not step on each others toes and also to enhance our work because each can do a different part. Also, each likely only has one person working on this, so that isn't that many people really, and they also have other issues they have to cover, compared to CEFIC, they have like 140 people here spending about $100 \%$ of their time on REACH.

While policymakers in the EU may be less responsive to coalition communications because of their limited electoral accountability, one of the alternative explanations - that the advocacy communities in the US and the EU are composed of different types of actors, more specialized in the US, broader in the EU - also finds some support. Since EU umbrella organizations are alliances of national associations, they already represent a number of organizations and thus don't find it necessary to ally with other interest groups. As one industry lobbyists succinctly put it: "We are the entire industry, so we don’t really work with any other organizations.” A trade association active on the REACH debate conveyed a similar logic: "Since we are an umbrella organization of 50 national and sectoral associations we are in a way a coalition.”

It is difficult to discount the other two alternative hypothesis - regarding multilevel governance and resource scarcity in the EU - but no evidence for them emerged from advocates' discussions of their coalition activity. I did ask advocates if they were also pursuing the national route as part of the larger project from which this 
data stems and none of the 82 lobbyists mentioned an ad hoc issue coalition which was established in any of the member states. A larger study that would specifically collect data on coalition activity at both the national and European level would be needed to accurately assess if this factor plays a role in lack of coalition formation in Brussels. Many actors in the EU did mention lack of funds, and the inability of their constituent members to see the importance of contributing money for representation in Brussels, but much the same complaints could be heard from the US lobbyists. Even the largest lobbies consistently feel their industry, sector or membership do not invest enough in their government relations activity. Moreover, while the lobbying industry as a whole may be better funded in the US, this should perhaps lead to more coalition activity in the EU rather than less. Coalitions do not necessarily require dues from the members; they can also be more of a work sharing framework to erase redundancies. If there is a set of interest groups which share the same goal on an individual issue and who are resourcepoor, they could coordinate their efforts - divvying up MEPs to visit and tactics to pursue. Net lack of resources in the EU therefore does not seem to be the strongest explanation for the lack of coalition activity in the EU. I look at the role of resources more directly within the US and the EU under the interest group characteristics section below.

In sum, we see evidence that the democratic institutional design of a polity plays a role in coalition activity. Coalitions in any polity offer the potential to pool resources and thus there is an incentive to forge coalitions. However, there is an added incentive to forge coalitions in systems were policymakers are accountable to the public in direct elections, since those officials need to ensure the votes they take on individual policy 
proposals are supported by large portions of the electorate. Ad hoc issue coalitions convey to elected officials the size and breadth of support for a proposal; and this may drive more coalition activity in the US than the EU.

\section{Issues}

The institutional structure within which an advocate is working is not, of course, the only consideration when deciding to join an issue coalition.

\section{[Table 1 here]}

As discussed in the theoretical section, previous scholarship has suggested that issues characterized by high conflict may lead advocates to band together. The findings show that indeed this is the case in the EU, where the highest percentage of advocates joining coalitions are doing so on issues that have opposing perspectives fighting against each other. In the US, however, the data is more ambiguous. Table 1 suggests advocates are most likely to join coalitions on issues that have a number of different perspectives, but not necessary in direct opposition to each other. These are issues where camps of advocates are promoting different ways to solve a political problem. It is important however to not over-interpret the finding since the number of observations is rather small for this category. Issues characterized by no conflict differ from cases with numerous perspectives or directly opposing perspectives. On issues with some level of conflict or intense conflict, advocates have an incentive to ban together.

Regarding issue scope, there is a clear pattern among advocates in the US; as the scope of their issue increases, they are more likely to join a coalition. Twenty-one percent of advocates that join coalitions are active on issues that will only impact a small sector, 
and $30 \%$ of joining advocates are active on those impacting large and multiple sectors, while $40 \%$ of advocates that decide to ally do so on the largest scope issues with systemwide ramifications. There is no clear relationship in the EU system between issue scope and coalition activity.

The other hypothesized relationship - that increasing public salience will lead to coalition membership - is also supported by the data but the effect only requires that there be some level of coverage of the issue in the news, there needn’t be hundreds of stories. In both the US and the EU, coalition membership is most likely when there is some level (even low) of news coverage of the issue.

The findings suggest that conflict and salience do play a role in the decision to join a coalition, while issue scope is only influential in the US. However, factors at the advocate level also play a role. I turn to those now.

\section{Interests}

The expectations about organizational resources are not born out in the findings, as presented in Table 1. It is not the poorest organizations that need to pool resources and thus join coalitions, but rather it is the wealthier organizations that are engaging in this lobbying strategy. ${ }^{3}$ This may be because resource-poor organizations do not feel they can spare funding to donate it to a coalition of organizations; or that coalition membership is more cost-intensive than scholars have realized - in time, money, and labor. The effort and energy expended hashing out a common position that is accepted by all coalition members could be saved if an organization decided to go it alone and were thus able to make the final call on all advocacy decisions. 
Turning to the second interest-group-level factor that was hypothesized to play a role in coalition membership, the type of actor does influence whether the advocate chooses to go it alone or band together with like-minded actors. The findings differ from expectations following from Clark and Wilson (1961) that ideological groups may be constrained from working with other organizations. In the US, citizen groups are the most likely to engage in coalition activities, with $50 \%$ of citizen group advocates reporting coalition activity compared to the average of $29 \%$. The next most likely are trade associations, which report joining ad hoc coalitions at 42\%. In the EU, trade associations are the type of advocate most commonly active in coalitions. However, citizen groups are second most likely to engage in coalition activity and they are the only other actor type that reported doing so. Taken together, these findings suggest citizen groups in both the US and the EU have a tendency to ally, but that they must have some level of resources to foot the bill that coalition activity requires.

\section{Conclusion}

Understanding the decision to join a coalition requires contextual and interest group information. The institutional design of the system in which an advocate is operating is critical. Will policymakers respond to lobbying tactics aimed at signalling the support of large swaths of the electorate? If not, is there much sense in putting resources into coalition building and coordinating? The data gathered from lobbyists in the US and the EU suggests the answer is no. The democratic accountability of policymakers appears to play a role in the decision to form and join coalitions.

However, we also saw evidence that the differences in the composition of the US and EU advocacy communities may also affect the propensity of EU groups to align, 
since larger pan-European federations don't see the same benefits as smaller specialized US groups.

The democratic accountability of policymakers remains a strong explanation for the differences we find between the US and the EU. It must be noted that this is not to say that the U.S. system is an ideal type. On the contrary, direct elections in the U.S. lead to perverse imbalances of power. While American policymakers are very much driven by the re re-election motive, they are not driven to be equally responsive to all constituents. This is because direct elections in the U.S. are coupled with private financing of elections. While it is always difficult to prove categorically, a great deal of evidence exists to suggest that policymakers are more responsive to wealthy interests that are able to aid in funding the re-election campaign. Lacking direct elections and thus financing of elections, the EU is free of such a biasing force. However, it can not be argued that the difference in institutional forms (elections versus appointment) lead to diverging motivational forces for US and EU policymakers and consequently to different advocacy strategies (coalition formation vs. networking) for advocates in the two polities.

Institutional explanations are only part of the story. Though coalition signals may be more useful in the US, they still are not ubiquitous. Likewise, coalitions are not totally absent from the EU scene. Issue characteristics also play a role; US advocates ally more often on issues with multiple viewpoints, with a larger societal impact and some level of salience. The same pattern is evident in the EU. Finally, the characteristics of the advocate themselves determine if they will work closely with other organizations in an ad hoc issue coalition. Different types of actors engage in coalition activity at varying levels. Importantly, citizen groups in both systems see an advantage is banning together and, in 
the process, showing their solidarity and pooling their resources. Finally, coalition membership requires some threshold of resources in both polities, with advocates supported by medium and large offices more likely to engage in coalition activity. The data presented here on the influence of institutions, issues and interests on coalition activity has driven home the point: To understand the decision to ally or forge ahead alone we must look to the broader political context and the character of the advocate. 
Figure 1. Coalition Activity in the US and the EU
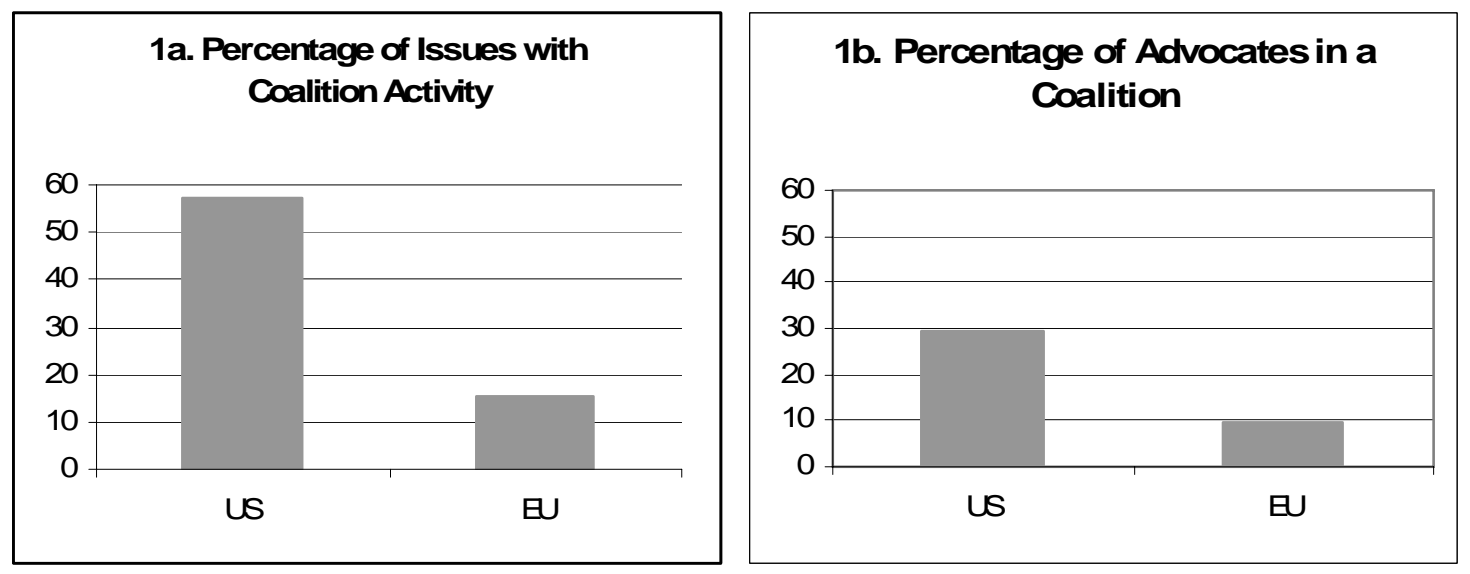
Table 1. Coalition Membership by Issue \& Interest Characteristics

\begin{tabular}{|c|c|c|c|c|c|}
\hline \multirow[b]{2}{*}{ Conflict } & \multicolumn{2}{|l|}{ US } & \multicolumn{3}{|c|}{ EU } \\
\hline & Freq. & $\mathbf{N}$ & & eq. & $\mathbf{N}$ \\
\hline None & $29 \%$ & 21 & None & $6 \%$ & 16 \\
\hline Multiple P & $67 \%$ & 3 & Multiple P & $0 \%$ & 7 \\
\hline Opposing & $27 \%$ & 41 & Opposing & $12 \%$ & 59 \\
\hline Scope & & & & & $\mathbf{N}$ \\
\hline Small sector & $22 \%$ & 23 & Small sector & $8 \%$ & 24 \\
\hline $\begin{array}{l}\text { Large Sector } \\
\text { Multiple }\end{array}$ & $32 \%$ & 22 & $\begin{array}{l}\text { Large Sector } \\
\text { Multiple }\end{array}$ & $17 \%$ & 23 \\
\hline Sectors & $30 \%$ & 10 & Sectors & $5 \%$ & 19 \\
\hline System-wide & $40 \%$ & 10 & System-wide & $6 \%$ & 16 \\
\hline Salience & & & & & $\mathbf{N}$ \\
\hline 0 stories & $33 \%$ & 30 & 0 stories & $9 \%$ & 32 \\
\hline 1-5 stories & $43 \%$ & 14 & 1-2 stories & $20 \%$ & 20 \\
\hline $6-50$ stories & $9 \%$ & 11 & 3 or more & $3 \%$ & 30 \\
\hline 51 or more & $20 \%$ & 10 & & & \\
\hline Total - N & 19 & 65 & & 8 & 82 \\
\hline Total - percent & $29 \%$ & & & $10 \%$ & \\
\hline
\end{tabular}

\begin{tabular}{|c|c|c|c|c|c|}
\hline \multirow[b]{2}{*}{ Staff } & \multicolumn{2}{|l|}{ US } & \multicolumn{3}{|c|}{ EU } \\
\hline & Freq. & $\mathbf{N}$ & & $q$. & $\mathbf{N}$ \\
\hline 1 to 5 & $29 \%$ & 14 & 1 to 5 & $3 \%$ & 30 \\
\hline 6 to 20 & $44 \%$ & 18 & 6 to 20 & $16 \%$ & 38 \\
\hline 21 or more & $50 \%$ & 14 & 21 or more & $7 \%$ & 14 \\
\hline Total - N & 19 & 46 & & 8 & 82 \\
\hline Total - percent & $41 \%$ & & & $10 \%$ & \\
\hline Type & & $\mathbf{N}$ & & & $\mathbf{N}$ \\
\hline Citizen & $50 \%$ & 10 & Citizen & $6 \%$ & 16 \\
\hline Foundation & $38 \%$ & 8 & Foundation & $0 \%$ & 3 \\
\hline Trade & $42 \%$ & 19 & Trade & $15 \%$ & 46 \\
\hline Corporations* & $33 \%$ & 9 & Hired Firms* & $0 \%$ & 7 \\
\hline Government & $0 \%$ & 19 & Government & $0 \%$ & 10 \\
\hline Total - N & 19 & 65 & & 8 & 82 \\
\hline Total - percent & $29 \%$ & & & $10 \%$ & \\
\hline
\end{tabular}


Address for Correspondence:

Christine Mahoney, Ph.D.

Moynihan European Research Centers

Moynihan Institute of Global Affairs

Maxwell School of Syracuse University

Syracuse, NY 13244-1020, USA

Office: +1 3154432935

ChristineMahoney04@fulbrightweb.org 


\section{Notes:}

${ }^{1}$ The US interviews were carried out in 2002 under the Baumgartner, Berry, Hojnacki, Leech, and Kimball project -- Advocacy \& Pubic Policymaking Project - NSF grants \# SES-0111224 and SBR-9905195. The EU interviews were carried out during 2004-5 with the support of a Fulbright Fellowship. Analysis was supported by a Fellowship from the Pennsylvania State University.

${ }^{2}$ For a full description of the 47 issues please visit: http://www.personal.psu.edu/cxm548

${ }^{3}$ Note: Congressional advocates are left out of this analysis, thus it is run on an $\mathrm{N}$ of 46 . 


\section{References}

Arnold, R. D. (1990) The Logic of Congressional Action, New Haven: Yale University Press.

Baumgartner, F.R. and Leech, B.L.. (2001) 'Interest Niches and Policy Bandwagons: Patterns of Interest Group Involvement in National Politics’, Journal of Politics 64: 1191-1213.

Berry, J. (1989) The Interest Group Society. 2d ed. New York: HarperCollins.

Beyers, J. (2002) 'Gaining and seeking access: The European adaptation of domestic interest associations’, European Journal of Political Research 41: 586-612.

Bouwen, P. (2002) 'Corporate lobbying in the European Union: the logic of access', Journal of European Public Policy Vol. 9 No. 3. pp365-390

Browne. W.P. (1990) 'Organized Interests and their Issue Niches: A Search for Pluralism in a Policy Domain’, Journal of Politics 52: 477-509.

Caldeira, G., and Wright, J. R. (1990) ‘Amici Curiae Before the Supreme Court: Who Participates, When, and How Much?', The Journal of Politics 52:782-806.

Clark, P. B. and Wilson, J. Q. (1961) 'Incentive Systems: A Theory of Organizations’, Administrative Science Quarterly 6:129-66.

Coen, D. (1997) 'The Evolution of the large firm as a political actor in the European Union', Journal of European Public Policy 4, 1:91-108

Coen, D. (2004) 'Environmental and Business Lobbying Alliances in Europe: Learning from Washington?', in Business in International Environmental Governance: A Political Economy Approach, D. Levy and P. Newell, (eds) Cambridge, Mass.: MIT Press. pp. 197-220. 
Cress, D. and Snow, D. (1998) 'Mobilization at the Margins: Organizing by the Homeless', in Social Movements and American Political Institutions. A. Costain and A. McFarland (eds.) pp. 73-98.

Esterling, K. M. (2005) The Political Economy of Expertise: Information and Efficiency in American National Politics, Ann Arbor: University of Michigan Press.

Follesdal, Andreas and Hix, Simon. (2006) 'Why there is a Democratic Deficit in the EU: A Response to Majone and Moravcsik’ Journal of Common Market Studies. Vol. 44, No. 3, pp. 533-62

Gais, T. and Walker Jr., J.L. (1991) 'Pathways to Influence in American Politics’, in Mobilizing Interest Groups in America, J. L. Walker, Jr. Ann Arbor: University of Michigan.

Heaney, M.T. (2004) ‘Reputation and Leadership inside Interest Group Coalitions’, Paper presented at the annual meetings of the American Political Science Association, Chicago, IL.

Heclo, H. (1978) 'Issue Networks and the Executive Establishment', in The New American Political System, Anthony King, (ed.) Washington: American Enterprise Institute.

Hojnacki, M. (1997) 'Interest Groups’ Decisions to Join Alliances or Work Alone’, American Journal of Political Science 41: 61-87.

Hojnacki, M. (1998) ‘Organized Interests’ Advocacy Behavior in Alliances’, Political Research Quarterly 51:437-59. 
Holyoke, T. (2004) 'Giving a Little to Get a Little: A Bargaining Model of Interest Group Coalition Formation', Paper presented at the American Political Science Association annual meetings. Chicago, Illinois. September 2004.

Hula, K. (1995) 'Rounding Up the Usual Suspects: Forging Interest Group Coalitions’, in Interest Group Politics, $4^{\text {th }}$ ed., A. J. Cigler and B. A. Loomis (eds.) Washington, DC: CQ Press.

Hula, K. W. (1999) Lobbying Together: Interest Group Coalitions in Legislative Politics, Washington, D.C.: Georgetown University Press.

Imig D. and Tarrow S. (eds.) (2001). Contentious Europeans: Protest and Politics in an Emerging Polity. Lanham, MD:Rowman \& Littlefield Publishers.

Kingdon, J. W. (1995) Agendas, Alternatives, and Public Policies, $2^{\text {nd }}$ ed. New York NY: HarperCollins.

Kohler-Koch, B. (1994) 'Changing patterns of interest intermediation in the European Union’, Government \& Opposition Vol. 29 pp 166-189.

Kreppel, Amie. (2001) The European Parliament and Supranational Party System. Cambridge: Cambridge University Press.

Lahusen, C. (2002) 'Commercial consultancies in the European Union: the shape and structure of professional interest intermediation', Journal of European Public Policy. 9:695-714.

Mahoney, C., and Baumgartner. F.R. (2004) 'The Determinants and Effects of InterestGroup Coalition Behaviors’, Paper presented at the American Political Science Association annual meetings. Chicago, Illinois. September 2004. 
Mayhew, D. (1974) Congress: The Electoral Connection, New Haven, Conn.: Yale University Press.

McCarthy, J. D., and Zald, M.N. (1978) 'Resource Mobilization and Social Movements: A Partial Theory', American Journal of Sociology 82: 1212-41.

McLaughlin, A., Jordan, G. and Maloney, W.A. (1993) 'Corporate lobbying in the European Community', Journal of Common Market Studies 31(2) 191-212.

Pijnenburg, B. (1998) ‘EU Lobbying by ad hoc Coalitions: an Exploratory Case Study’, Journal of European Public Policy 14, 2: 95-145

Pollack. M. (1997) ‘Representing Diffuse Interests in EC Policy-making’, Journal of European Public Policy. 4, 4:572-90

Princen, S. and Kerremans, B. (2005) 'Opportunity structures in the EU multi-level system', Paper presented at the CONNEX research group 4 Civil society and interest representation in EU-governance. Leiden, NL, 14-16 April 2005.

Sabatier, P. A. (1988) 'An Advocacy Coalition Framework of Policy Change and the Role of Policy-Oriented Learning Therein', Policy Sciences 21: 129-68.

Salisbury, R. H., Heinz J.P., Laumann, E.O. and Nelson, R. (1987) 'Who Works With Whom? Interest Group Alliances and Opposition', American Political Science Review 81:1211-34.

Salisbury, R.H. (1984) 'Interest Representation: The Dominance of Institutions’, American Political Science Review 78: 64-76.

Walker, J. (1991) Mobilizing Interest Groups in America, Ann Arbor: University of Michigan Press. 
Weiler, Joseph H.H., Ulrich R. Haltern, and Franz C. Mayer (1995) ‘European Democracy and its Critique.' West European Politics, Vol. 18 No. 3, pp. 4-39.

Whitford, A. B. (2003) 'The Structures of Interest Coalitions: Evidence from Environmental Litigation', Business and Politics 5:45-64. 
Word Count: 8,719

\section{Biographical Note:}

Dr. Christine Mahoney is a Postdoctoral Fellow at Syracuse University's European Union Center of Excellence, in the Moynihan Institute of Global Affairs. Her research focuses on civil society and advocacy in the United States, the European Union and the developing world. Her book Advocacy in the United States and the European Union is under contract with Georgetown University Press. She has also published in European Union Politics and the Journal of Public Policy. 